\title{
Animasi 3 Dimensi Pencegahan Cyber Crime (Studi Kasus : Kota Manado)
}

\author{
Alan Stevenres Bentelu ${ }^{(1)}$, Steven Sentinuwo ${ }^{(2)}$, Oktavian Lantang ${ }^{(3)}$ \\ Teknik Informatika, Universitas Sam Ratulangi, Manado, Indonesia. \\ Email: alanstevenres@gmail.com 2 steven@unsrat.ac.id, oktavian@unsrat.ac.id
}

\begin{abstract}
Abstrak - Cyber Crime atau kejahatan dunia maya merupakan jenis kejahatan yang lahir karena pesatnya perkembangan teknologi informasi dan komunikasi. Tujuan pembuatan Animasi 3 Dimensi Pencegahan Cyber Crime adalah membuat video animasi 3 dimensi untuk menyampaikan pesan mengenai Cyber Crime dan pencegahannya. Software $3 D$ yang digunakan dalam pembuatan animasi ini adalah Blender, untuk proses Modelling, Texturing, Rigging, Lighting, Animating, Camera operation dan Render awal. Adobe Sounbooth untuk perekaman suara dan Adobe premiere Pro CS6 untuk menggabungkan hasil rendernya. Metode perancangan yang digunakan dalam pembuatan animasi ini adalah Development, Pra-Produksi, Produksi, Pasca Produksi. Hasil yang dicapai adalah video ini bisa menjadi video animasi yang informatif dan menarik.
\end{abstract}

Kata Kunci: Cyber crime, Animasi 3 dimensi, Development, Produksi, Software 3D.

\section{PENDAHULUAN}

Perkembangan teknologi dan informasi sudah menjadi sebuah kebutuhan penting bagi manusia, yang mana banyak tercipta ruang untuk lebih mengembangkan teknologi tersebut dengan berbagai inovasi dan pengetahuan baru kedepannya.

Kota Manado adalah ibu kota dari provinsi Sulawesi Utara. Sebagai ibukota dari provinsi Sulawesi Utara, pemanfaatan teknologi informasi dan komunikasi telah menjadi kebutuhan sebagian besar masyarakat dan menyebabkan perubahan sosial, ekonomi, dan budaya. Perkembangan yang pesat dalam pemanfaatan teknologi Informasi dan komunikasi tak hanya membawa dampak positif bagi para penggunanya, tetapi juga dampak negatif bila para pengguna tidak berhati-hati dalam memanfaatkan teknologi ini.

Cyber crime (kejahatan dunia maya) merupakan jenis kejahatan yang lahir karena pesatnya perkembangan teknologi informasi dan komunikasi. Oleh karena itu masyarakat sudah selayaknya memahami DUTY CARE (Prinsip kehati-hatian) dalam menggunakan media teknologi informasi dan komunikasi dan adanya hukum UU ITE (UndangUndang Informasi dan Transaksi Elektronik) atas tindakan Cyber crime.

Dalam hal ini penulis akan membuat video Animasi 3 Dimensi Pencegahan Cyber Crime. Dalam rangka untuk memperoleh informasi yang lebih spesifik tentang Cyber Crime Penulis melakukan penelitian di kantor POLDA Sulawesi Utara untuk memenuhi kriteria pembuatan animasi layanan masyarakat khususnya dalam kasus Cyber Crime.
Berdasarkan uraian diatas maka penulis mencoba untuk membuat sebuah iklan layanan masyarakat tentang Animasi 3 Dimensi Pencegahan Cyber Crime. Karya ini diharapkan dapat menjadi solusi yang tepat, informatif dan bermanfaat untuk memberikan informasi yang berguna bagi masyarakat mengenai pentingnya sikap waspada dalam menggunakan media online, melakukan transaksi dan sebagainya.

\section{LANDASAN TEORI}

\section{A. Definisi Multimedia}

Dalam perkembangan multimedia dari dulu hingga saat ini, terdapat berbagai pengertian yang telah dikemukakan. Menurut McCormick (1996) oleh Suyanto, M. (2005) menyatakan bahwa "multimedia secara umum merupakan kombinasi tiga elemen, yaitu suara, gambar dan teks."

Turban dkk (2002) oleh Suyanto, M. (2005) menyatakan bahwa "multimedia adalah kombinasi dari paling sedikit dua media input atau output dari data, media ini dapat audio (suara, musik), animasi, video, teks, grafik dan gambar."

Robin dan Linda (2001) oleh Suyanto, M. (2005) menyatakan bahwa "multimedia merupakan alat yang dapat menciptakan presentasi yang dinamis dan interaktif yang mengombinasikan teks, grafik, animasi, audio dan gambar video."

Hofstetter, (2001) oleh Suyanto, M. (2005) menyatakan bahwa "multimedia adalah pemanfaatan komputer untuk membuat dan menggabungkan teks, grafik, audio, gambar bergerak (video dan animasi) dengan menggabungkan link dan tool yang memungkinkan pemakai melakukan navigasi, berinteraksi, berkreasi dan berkomunikasi. Dalam definisi ini terkandung empat komponen penting multimedia. Pertama, harus ada komputer yang mengkoordinasikan apa yang dilihat dan didengar, yang berinteraksi dengan kita. Kedua, harus ada link yang menghubungkan kita dengan informasi. Ketiga, harus ada alat navigasi yang memandu kita, menjelajah jaringan informasi yang saling terhubung. Keempat, multimedia menyediakan tempat kepada kita untuk mengumpulkan, memproses dan mengkomunikasikan informasi dan ide kita sendiri." ${ }^{[5]}$

\section{B. Definisi Animasi}

Pengertian Animasi Menurut Ibiz Fernandes dalam bukunya Macromedia Flash Animation \& Cartooning: A creative Guide, animasi definisikan sebagai berikut : 
"Animation is the process of recording and playing back a sequence of stills to achieve the illusion of continues motion" (Ibiz Fernandez McGrawHill/Osborn, California, 2002).

Yang artinya adalah : "Animasi adalah sebuah proses merekam dan memainkan kembali serangkaian gambar statis untuk mendapatkan sebuah ilusi pergerakan." Berdasarkan arti harfiah, Animasi adalah menghidupkan. Yaitu usaha untuk menggerakkan sesuatu yang tidak bisa bergerak sendiri.

Secara garis besar, animasi computer dibagi menjadi dua kategori, yaitu:

a. Computer Assisted Animation, animasi pada kategori ini biasanya menunjuk pada system animasi 2 dimensi, yaitu mengkomputerisasi proses animasi tradisional yang menggunakan gambaran tangan. Computer digunakan untuk pewarnaan, penerapan virtual kamera dan penataan data yang digunakan dalam sebuah animasi.

b. Computer Generated Animation, pada kategori ini biasanya digunakan untuk animasi 3 dimensi dengan program 3D seperti 3D Studio Max, Maya, Autocad, Blender dll. ${ }^{[3]}$

\section{Cyber crime}

Cyber crime adalah kejahatan dunia maya (Inggris: cybercrime) adalah istilah yang mengacu kepada aktivitas kejahatan dengan komputer atau jaringan komputer menjadi alat, sasaran atau tempat terjadinya kejahatan. Termasuk ke dalam kejahatan dunia maya antara lain adalah penipuan lelang secara online, pemalsuan cek, penipuan kartu kredit/carding, confidence fraud, penipuan identitas, pornografi anak, dll.

Percepatan teknologi semakin lama semakin supra yang menjadi sebab material perubahan yang terus menerus dalam semua interaksi dan aktivitas masyarakat informasi. Internet merupakan symbol material embrio masyarakat global. Internet membuat globe dunia, seolah-olah menjadi seperti hanya selebar daun kelor. Era informasi ditandai dengan aksesibilitas informasi yang amat tinggi. Dalam era ini, informasi merupakan komoditi utama yang diperjual belikan sehingga akan muncul berbagai network dan information company yang akan memperjual belikan berbagai fasilitas bermacam jaringan dan berbagai basis data informasi tentang berbagai hal yang dapat diakses oleh pengguna dan pelanggan. Sebenarnya dalam persoalan cybercrime, tidak ada kekosongan hukum, ini terjadi jika digunakan metode penafsiran yang dikenal dalam ilmu hukum dan ini yang mestinya dipegang oleh aparat penegak hukum dalam menghadapi perbuatanperbuatan yang berdimensi baru yang secara khusus belum diatur dalam undang-undang. Dalam beberapa literatur, cybercrime sering diidentikkan sebagai computer crime.

Pengertian Cybercrime Menurut Beberapa Ahli :

- Andi Hamzah dalam bukunya "Aspek-aspek Pidana di Bidang Komputer" (1989) mengartikan cybercrime sebagai kejahatan di bidang komputer secara umum dapat diartikan sebagai penggunaan komputer secara ilegal.
- Forester dan Morrison mendefinisikan kejahatan komputer sebagai: aksi kriminal dimana komputer digunakan sebagai senjata utama.

- Girasa (2002) mendefinisikan cybercrime sebagai aksi kejahatan yang menggunakan teknologi komputer sebagai komponen utama.

- Tavani (2000) memberikan definisi cybercrime yang lebih menarik, yaitu: kejahatan dimana tindakan kriminal hanya bisa dilakukan dengan menggunakan teknologi cyber dan terjadi di dunia cyber.

\section{Undang Undang Informasi dan Transaksi Elektronik}

Undang-undang Informasi dan Transaksi Elektronik adalah ketentuan yang berlaku untuk setiap orang yang melakukan perbuatan hukum sebagaimana diatur dalam Undang-Undang ini, baik yang berada di wilayah hukum Indonesia maupun di luar wilayah hukum Indonesia, yang memiliki akibat hukum di wilayah hukum Indonesia dan/atau di luar wilayah hukum Indonesia dan merugikan kepentingan Indonesia

Secara umum, materi Undang-Undang Informasi dan Transaksi Elektronik (UUITE) dibagi menjadi dua bagian besar, yaitu pengaturan mengenai informasi dan transaksi elektronik dan pengaturan mengenai perbuatan yang dilarang. Pengaturan mengenai informasi dan transaksi elektronik mengacu pada beberapa instrumen internasional, seperti UNCITRAL Model Law on eCommerce dan UNCITRAL Model Law on eSignature. Bagian ini dimaksudkan untuk mengakomodir kebutuhan para pelaku bisnis di internet dan masyarakat umumnya guna mendapatkan kepastian hukum dalam melakukan transaksi elektronik. Beberapa materi yang diatur, antara lain: 1. pengakuan informasi/dokumen elektronik sebagai alat bukti hukum yang sah (Pasal 5 \& Pasal 6 UU ITE); 2. tanda tangan elektronik (Pasal 11 \& Pasal 12 UU ITE); 3. penyelenggaraan sertifikasi elektronik (certification authority, Pasal 13 \& Pasal 14 UU ITE); dan 4. penyelenggaraan sistem elektronik (Pasal 15 \& Pasal 16 UU ITE);

Beberapa materi perbuatan yang dilarang (cybercrimes) yang diatur dalam UU ITE, antara lain: 1. konten ilegal, yang terdiri dari, antara lain: kesusilaan, perjudian, penghinaan/pencemaran nama baik, pengancaman dan pemerasan (Pasal 27, Pasal 28, dan Pasal 29 UU ITE); 2. akses ilegal (Pasal 30); 3. intersepsi ilegal (Pasal 31); 4. gangguan terhadap data (data interference, Pasal 32 UU ITE); 5. gangguan terhadap sistem (system interference, Pasal 33 UU ITE); 6. penyalahgunaan alat dan perangkat (misuse of device, Pasal 34 UU ITE) ${ }^{[6]}$

\section{E. Duty Care}

Dimana seseorang atau suatu instansi harus berhatihati dalam menggunakan suatu media untuk memenuhi tanggung jawab profesional dengan kompetensi dan ketekunan. Hal ini berarti bahwa 
anggota mempunyai kewajiban untuk melaksanakan jasa profesional dengan sebaik-baiknya sesuai dengan kemampuan demi kepentingan pengguna jasa dan konsisten dengan tanggung jawab profesi kepada publik. Menurut PSA (Pernyataan Standar Auditing) no. 4 SPAP (2001), kecermatan dan keseksamaan dalam penggunaan kemahiran profesional menuntut auditor untuk melaksanakan skeptisme profesional, yaitu sikap auditor yang berfikir kritis terhadap bukti audit dengan selalu mempertanyakan dan melakukan evaluasi terhadap bukti audit tersebut. ${ }^{[2]}$

\section{F. Blender}

Menurut Lucky Maharani dkk, (2014) Pada tahun 1988 Ton Roosendaal mendanai perusahaan yang bergerak dibidang animasi yang dinamakan NeoGeo. NeoGeo adalah berkembang pesat sehingga menjadi perusahaan animasi terbesar di Belanda dan salah satu perusahaan animasi terdepan di Eropa. Ton Roosendaal selain bertanggung jawab sebagai art director juga bertanggung jawabatas pengembangan software internal.

Pada tahun 1995 muncullah sebuah software yang pada akhirnya dinamakan Blender. Setelah diamati ternyata Blender memiliki potensi untuk digunakan oleh artis -artis diluar NeoGeo. Lalu pada tahun 1998 Ton mendirikan perusahaan yang bernama Not a Number (NaN) Untuk mengembangkan dan memasarkan Blender lebih jauh. Cita - cita NaN adalah untuk menciptakan sebuah software animasi 3D yang padat, cross platform yang gratis dan dapat digunakan oleh masyarakat computer yang umum.

Sayangnya ambisi NaN tidak sesuai dengan kenyataan pasar saat itu. Tahun $2001 \mathrm{NaN}$ dibentuk ulang menjadi perusahaan yang lebih kecil $\mathrm{NaN}$ lalu meluncurkan software komersial pertamanya, Blender Publisher. Sasaran pasar software ini adalah untuk web 3D interaktif. Angka penjualan yang rendah dan iklim ekonomi yang tidak menguntungkan saat itu mengakibatkan NaN ditutup. Punutupan ini termasuk penghentian terhadap pengembangan Blender.

Karena tidak ingin Blender hilang ditelan waktu begitu saja, Ton Roosendaal mendirikan organisasi non profit yang bernama Blender Foundation. Tujuan utama Blender Foundation adalah terus mempromosikan dan mengembangkan Blender sebagai proyek open source. Pada tahun 2002 Blender dirilis ulang dibawah syarat - syarat GNU General Public License.

\section{G. Pengertian dan Kegunaan Blender}

Blender 3D adalah software gratis yang bisa digunakan untuk modeling, texturing, lighting, animating dan video post processing 3 dimensi. Blender 3D yang merupakan software gratis dan open source ini merupakan open source 3D paling populer di dunia. Fitur Blender 3D tidak kalah dengan software 3D berharga mahal seperti 3D studio max, maya maupun XSI. Dengan Blender 3D anda bisa membuat objek 3D animasi, media 3D interaktif, model dan bentuk 3D profesional, membuat objek game dan masih banyak lagi kreasi 3D lainnya.
Blender merupakan sebuah software pengolah 3 dimensi dan animasi yang compatible/dijalankan di beberapa OS, seperti;
- Windows
- Machintos
- IRIX
- Solaris
- NetBSD
- FreeBSD
- OpenBSD dan Linux.

Blender 3D memberikan kegunaan sebagai berikut :

- interface yang user friendly dan tertata rapi.

- Tool untuk membuat objek 3D yang lengkap meliputi modeling, UV mapping, texturing, rigging, skinning, animasi, particle dan simulasi lainnya, scripting, rendering, compositing, post production dan game creation.

- Cross Platform, dengan uniform GUI dan mendukung semua platform. Blender 3D bisa anda gunakan untuk semua versi windows, Linux, OS X, FreeBSD, Irix, Sun dan sistem operasi yang lainnya.

- Kualitas arsitektur 3D yang berkualitas tinggi dan bisa dikerjakan dengan lebih cepat dan efisien.

- Dukungan yang aktif melalui forum dan komunitas.

Jika dahulu membuat animasi membutuhkan aplikasi yang mahal dengan tingkat kerumitan yang tinggi, kini hal tersebut bisa diatasi dengan hadirnya Blender. Aplikasi yang namanya mirip peralatan dapur ini menawarkan penggunaan yang lebih mudah dan gratis pula. Pengertian mudah di sini memang bukan berarti segampang menggunakan aplikasi seharihari, tapi tetap saja, jika dibandingkan dengan aplikasi terdahulu yang membutuhkan skill tinggi, Blender menawarkan penggunaan yang lebih mudah.

Blender merupakan aplikasi pembuat grafis animasi 3D andalan pengguna Linux yang cukup bagus. Fiturnya lengkap, ringan, update-nya cepat, serta memiliki komunitas terbuka yang akan membantu para pengguna di seluruh dunia untuk saling bertukar pikiran. Hal inilah yang membuatnya makin menarik untuk dicoba. Apalagi kini ia telah hadir bagi sistem operasi seperti Windows, Mac OS, hingga Solaris.

Selain untuk membuat konten 3D, Blender juga dapat digunakan dalam berbagai kegiatan multimedia seperti mengedit video, membuat game, animasi, compositing, dan lainnya yang berhubungan dengan animasi 3D. Bahkan ada komunitas yang telah berhasil membuat sebuah film animasi 3D secara utuh dengan hanya menggunakan Blender

Menurut kebanyakan orang pengertian Blender adalah perangkat lunak untuk grafis 3 dimensi yang gratis dan populer di kalangan desainer. Blender dapat digunakan untuk membuat animasi 3dimensi Perangkat lunak ini juga memiliki fitur untuk membuat permainan. Blender tersedia untuk berbagai sistem operasi, seperti: Microsoft Windows, Linux, Mac OS $\mathrm{X}$ pun bisa. Fitur Blender tidak kalah dengan aplikasiaplikasi desain berbayar seperti 3d Studio Max, dan 
lainnya. Kemampuannya menciptakan modeling, compositing sampai animating tergolong sangat baik.

Blender sendiri merupakan sebuah software open source yang kini dikembangkan olehsebuah Organisasi Non profit di Belanda yang bernama Blender Foundation. Namun janganlah merendahkan pengguna Blender, karna isunya pembuat animasi 3D sedang berada diatas angin, Para pengguna Blender ini diburu lantaran masih sedikitnya sumber daya manusia yang dapt menggunakan Blender.

Komunitas ini didirikan oleh Hiza Ro pada bulan Agustus 2009 dengan modal semangat, keyakinan dan uang sebesar 100 ribu rupiah guna pembelian domain. Karena komunitas ini merupakan komunitas yang berkembang di dunia maya, sehingga siapapun bisa bergabung di dalamnya secara GRATIS. Selain bertemu secara online, para pengguna Blender terkadang melakukan gathering secara offline dalam bentuk kumpul-kumpul, seminar maupun workshop. Selain itu banyak juga studio animasi yang terlahir dari komunitas ini ${ }^{[1]}$

\section{H. Aplikasi Adobe Premiere}

Menurut Reskyanti (2012) Adobe Premiere adalah salah satu software yang popular dan digunakan secara luas dalam pengeditan video. Ada antarmuka yang sama dengan Adobe PhotoShop Adobe Premiere dan Adobe After Effects adalah untuk memberikan kemudahan penggunaan, gambar - gambar dapat dibuat dengan Adobe Photoshop dan efek - efek khusus juga dapat disiapkan dari adobe setelah efek.

Adobe Premiere merupakan program yang sudah umum digunakan oleh rumah-rumah produksi, televisi dan praktisi di bidangnya. Keuntungan belajar melakukan edit video menggunakan

Fungsi utama Adobe Premiere Pro lebih untuk merangkai gambar, video dan audio, bukan untuk animasi. Agar penampilan multimedia anda lebih menarik. ${ }^{[4]}$

\section{METODE PENELITIAN}

Pada metode atau langkah-langkah dalam perancangan terdapat tiga tahapan pembuatan yaitu : Tahap Pra-Produksi, Tahap Produksi Dan Tahap Pasca Produksi seperti pada Gambar 3.2

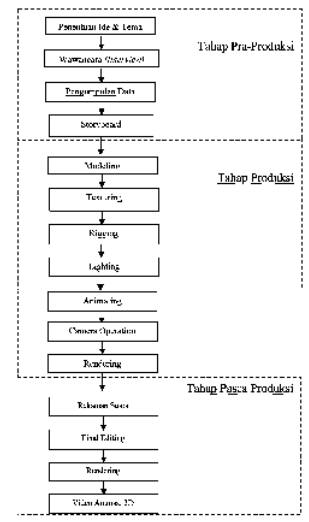

Gambar 3.1 Langkah-Langkah Perancangan Animasi 3D
A. Tahap Pra-Produksi

Penentuan Ide dan Tema

Penentuan Ide dan Tema merupakan tahap dimana penulis menentukan ide dan tema dari hasil wawancara di Kantor Polisi Daerah Sulawesi Utara (lihat gambar 3.3) dan hasil konsultasi dengan beberapa dosen sehingga menjadi judul skripsi Animasi 3 Dimensi Pencegahan Cyber Crime (Studi Kasus : Kota Manado)

\section{B. Wawancara}

Wawancara merupakan tahap dimana penulis bertanya langsung di Kantor Polisi Daerah Sulawesi Utara di bagian Perbankan Subdit Cyber Crime untuk Animasi 3 Dimensi Pencegahan Cyber Crime. Dengan bentuk pertanyaan sebagai berikut:

1. Apa defenisi pencegahan cyber crime menurut anda?

2. Apa saja kejahatan yang masuk dalam kategori cyber crime?

3. Sebutkan kasus 5 tahun terakhir dan jumlah masingmasing kasus

4. Tahapan-tahapan apa saja dalam tindakan pencegahan cyber crime?

Wawancara ini telah di lakukan pada Rabu 2 September 2015 kepada pegawai atau staf :

1. Nama : Ipda Daud D. Lepong Jabatan : Panit Perbankan Subdit Cybercrime

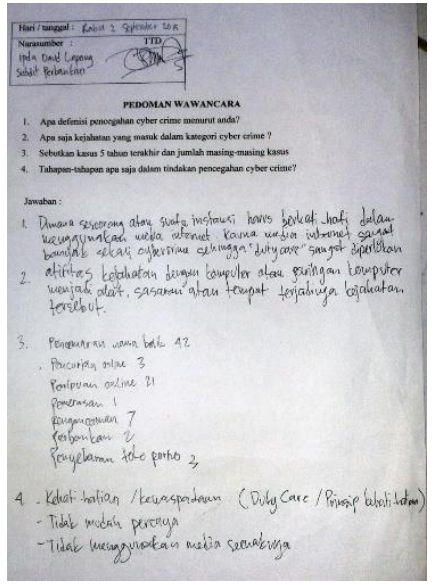

Gambar 3.2 Hasil wawancara kasus 5 tahun terakhir

C. Kuisioner

Berikut merupakan tabel daftar pertanyaan kuisioner yang di tujukan kepada beberapa masyarakat yang sering beraktifitas menggunakan media oline. Pemberian kuisioner talah di lakukan pada bulan agustus 2015.

Pada Tabel 3.1 merupakan tabel pertanyaan kuisioner nomor 1 (satu) dengan jumlah responden yang menjawab 7 (tujuh) orang dan semuanya menjawab Sangat Diperlukan. 
Tabel 3.1 Kuisioner Nomor 1

\begin{tabular}{|l|c|c|c|c|}
\hline \multirow{2}{*}{$\begin{array}{l}\text { Pertanyaan } \\
\text { Responden }\end{array}$} & $\begin{array}{c}\text { Jumlah } \\
\text { Resakah } \\
\text { menurut } \\
\text { anda } \\
\text { diperlukan }\end{array}$ & $\begin{array}{c}\text { Sangat } \\
\text { Diperlukan }\end{array}$ & Diperlukan & $\begin{array}{c}\text { Tidak } \\
\text { Diperlukan }\end{array}$ \\
$\begin{array}{l}\text { informasi } \\
\text { mengenai } \\
\text { cyber } \\
\text { crime dan } \\
\text { cara } \\
\text { pencegaha } \\
\text { nnya? }\end{array}$ & 7 & 7 & 0 & \\
& & & & \\
\hline
\end{tabular}

Selanjutnya pada Tabel 3.2 merupakan tabel pertanyaan kuisioner nomor 3 (tiga) dengan jumlah responden yang menjawab 7 (tujuh) orang dan semuanya menjawab "Sangat Perlu".

Tabel 3.2 Kuisioner Nomor 2

\begin{tabular}{|c|c|c|c|c|}
\hline \multirow{2}{*}{ Pertanyaan } & \multirow{2}{*}{$\begin{array}{c}\text { Jumlah } \\
\text { Responden }\end{array}$} & $\begin{array}{c}\text { Sangat } \\
\text { Perlu }\end{array}$ & Perlu & $\begin{array}{c}\text { Tidak } \\
\text { Perlu }\end{array}$ \\
\cline { 3 - 5 } & & & & \\
\hline $\begin{array}{l}\text { 2. Apakah menurut } \\
\text { anda perlu dibuat } \\
\text { penyampaian } \\
\text { informasi mengenai } \\
\text { pencegahan cyber } \\
\text { crime secara digital } \\
\text { menggunakan } \\
\text { Video Animasi 3 }\end{array}$ & 7 & 7 & 0 & 0 \\
Dimensi ? & & & & \\
\hline
\end{tabular}

Kemudian pada Tabel 3.3 merupakan tabel pertanyaan kuisioner nomor 2 (dua) dengan jumlah responden yang menjawab 7 (tujuh) orang dan semuanya menjawab "Sangat Dimengerti".

Tabel 3.3 Kuisioner Nomor 3

\begin{tabular}{|c|c|c|c|c|}
\hline \multirow{2}{*}{ Pertanyaan } & \multirow{2}{*}{$\begin{array}{c}\text { Jumlah } \\
\text { Responden }\end{array}$} & \multicolumn{3}{|c|}{ Jawaban } \\
\hline & & $\begin{array}{c}\text { Sangat } \\
\text { Dimengerti }\end{array}$ & Dimengerti & $\begin{array}{c}\text { Tidak } \\
\text { Dimengerti }\end{array}$ \\
\hline $\begin{array}{l}\text { 3. Apakah } \\
\text { menurut anda } \\
\text { proses } \\
\text { penyampaian } \\
\text { informasi } \\
\text { mengenai } \\
\text { cyber crime } \\
\text { dan cara } \\
\text { pencegahann } \\
\text { ya dalam } \\
\text { video } \\
\text { animasi } 3 \\
\text { dimensi } \\
\text { dapat } \\
\text { dimengerti ? }\end{array}$ & 7 & 7 & 0 & 0 \\
\hline
\end{tabular}

\section{HASIL DAN PEMBAHASAN}

\section{A. Tahap Produksi \\ Modeling Objek Pada Blender}

Pada perancangan dan pembuatan video animasi 3 dimensi pengujian kendaraan bermotor memakai objek Cube, UV Sphare, Plane dan cylinder. Kemudian proses pembentukan model objek dilakukan pada Edit Mode dengan bantuan fungsi ekstrude, skala, dan grab dan beberapa tool editor seperti Mirror Modifier dan Subdivision Surface sehingga terbentuklah model objek sesuai keinginan penulis. Model objek yang dibuat oleh penulis seperti pada Gambar 4.1

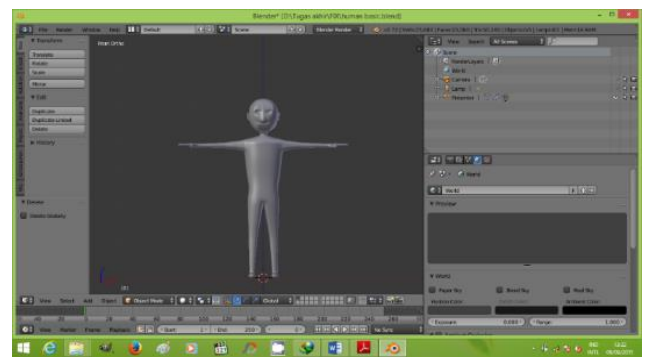

Gambar 4.1 Karakter Manusia Karakter Manusia setelah diaktifkan Mirror Modifier dan Subdivision Surface

\section{B. Teksturing}

Pada proses teksturing ini penulis menambahkan tekstur atau warna yang sesuai dengan objek aslinya sehingga terlihat lebih natural dan menarik. Proses teksturing dalam aplikasi blender dapat dibuat dengan menggunakan tools material yang ada pada kolom properties dan $U V$ map pada aplikasi blender, Teksturing objek yang dibuat oleh penulis seperti pada Gambar 4.2

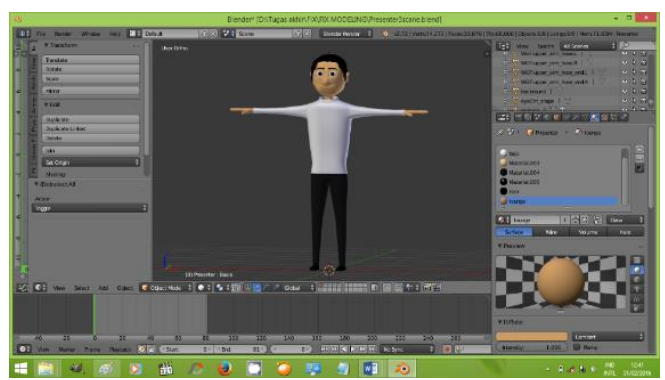

Gambar 4.2 Texturing karakter

\section{Riging}

Pada tahap riging ini penulis melakukan proses pemasangan tulang pada objek atau karakter di aplikasi Blender. Pemasangan tulang dilakukan pada saat objek manusia selesai dibuat dengan menggunakan tool Armature kemudian memilih Human Meta rig sebagai tulang manusia yang kemudian akan di modifikasi menjadi Control Shape key untuk menggerakan tubuh karakter, seperti pada Gambar 4.3 


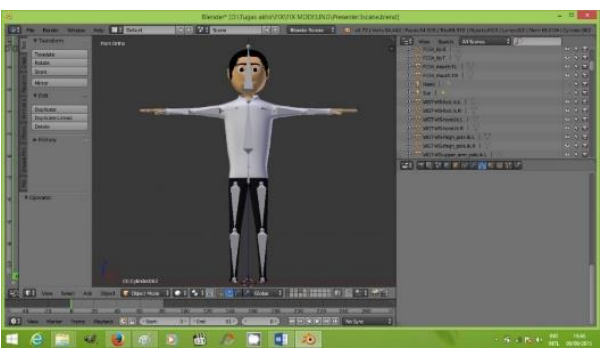

D. Lighting

Gambar 4.3 Rigging karakter

Pada tahap Lighting penulis melakukan proses pemberian cahaya pada model sehingga diperoleh kesan visual yang realistis, seperti pada gambar 4.4

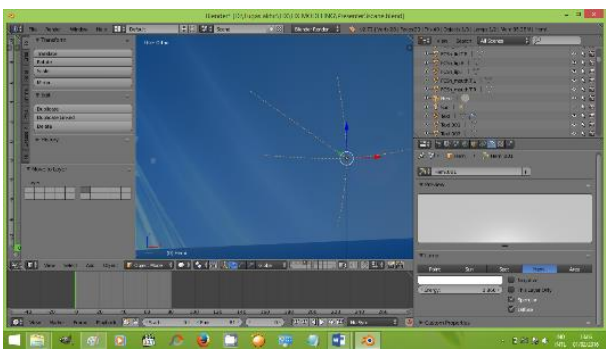

Gambar 4.4 Pengaturan lighting

\section{E. Animating}

Pada tahap Animating ini penulis melakukan pengaturan pergerakan objek animasi dengan memberikan gerakan pada objek maupun pada kemera sesuai storyboard., seperti pada Gambar 4.5

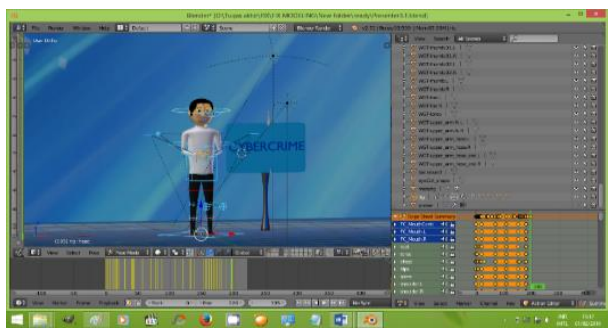

Gambar 4.5 Animating karater Presenter

\section{F. Camera Operation}

Pada tahap Camera Operation ini penulis melakukan pengoprasian kamera masih di dalam tools animattion agar dapat melihat pergerakan objek manusia dan merekam objek tersebut yang telah di animasikan oleh penulis, seperti pada Gambar 4.6

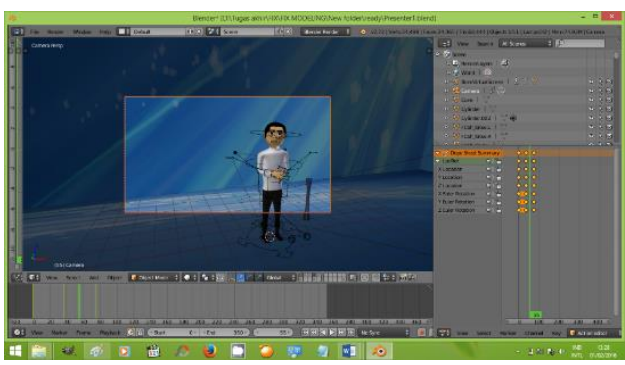

Gambar 4.6 Camera Operation untuk part karakter Presenter

\section{G. Rendering}

Pada tahap Rendering ini dilakukan untuk membuat animasi kedalam bentuk video 3 dimensi. Proses rendering dilakukan pada setiap adegan satu demi satu hingga menjadi beberapa video Animasi 3 Dimensi Pencegahan Cyber Crime. Proses rendering dilakukan pada tools render yang terdapat pada kolom proprties dengan menekan tombol Animation seperti pada Gambar 4.7

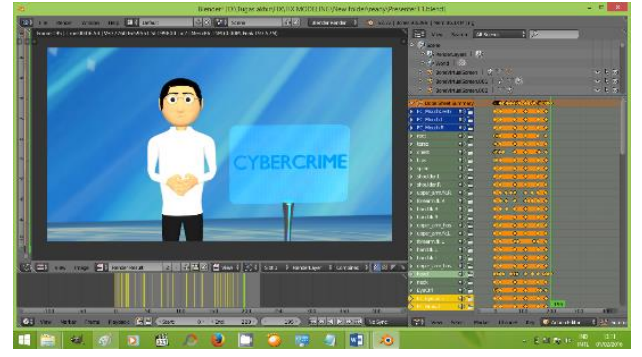

Gambar 4.7 Rendering part Presenter

\section{H. Tahap Pasca Produksi}

Rekam Suara

Proses perekaman suara dilakukan dengan aplikasi Adobe Soundbooth CS5 dengan format file perekaman menjadi format .wav, seperti pada Gambar 4.8

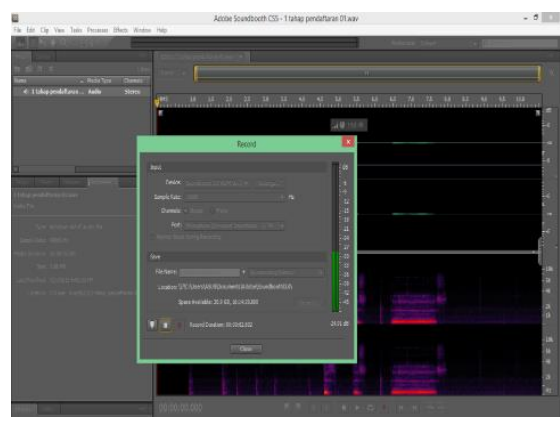

Gambar 4.8 Perekaman Suara

\section{Final Editing}

Final Editing merupakan proses dimana semua file video 3 dimensi hasil render pada aplikasi Blender dan file audio yang dibuat pada aplikasi Adobe SoundBooth diimport kedalam aplikasi Adobe Premiere Pro, seperti pada Gambar 4.9 yang kemudian akan di satukan.

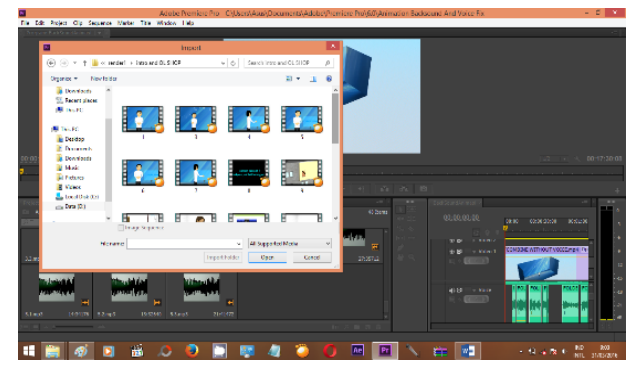

Gambar 4.9 Mengimport File-File Video kedalam aplikasi Adobe Premiere Pro 


\section{J. Final Rendering}

Final Rendering merupakan tahap akhir dari pembuatan video Animasi 3D pada aplikasi Adobe Premiere Pro CS5 dengan output Animasi 3 Dimensi Pencegahan Cyber Crime. Pada Gambar 4.10 merupakan proses mengexport file video Animasi 3 Dimensi Pencegahan Cyber Crime dari aplikasi Adobe Premiere Pro CS5 ke Adobe Media Enconder

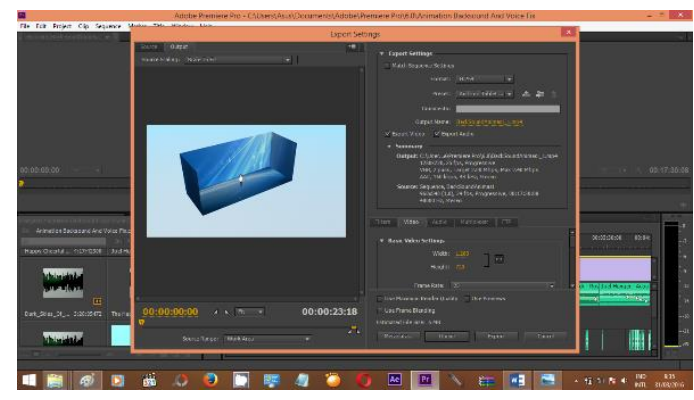

Gambar 4.10 Proses Mengexport Video dari Adobe Premiere Pro ke Adobe Media Enconder

\section{K. Hasil Video Animasi 3 Dimensi}

Gambar 4.11 adalah hasil dari video Animasi 3 Dimensi Pencegahan Cyber Crime contoh kasus pertama yang sudah menjadi format file avi beresolusi $1280 \times 720$ pixel berdurasi 5 menit 2 detik dan ukuran file 77.9 MB

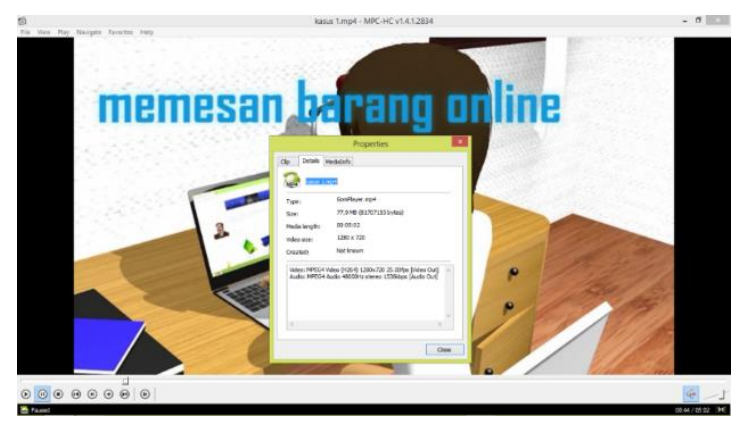

Gambar 4.11 Properties video Animasi 3 Dimensi Pencegahan Cyber Crime

\section{BAB V}

KESIMPULAN DAN SARAN

A. Kesimpulan

1. Video animasi 3 dimensi ini berhasil dibuat dan dapat memberikan pengetahuan bagi para pengguna media online mengenai Cyber Crime dan pencegahannya.

2. Dalam proses rendering awal, membutuhkan waktu yang cukup lama, seperti merender 1 part dalam video animasi yang memiliki banyak gerakan, modelling karakter yang memiliki mesh halus dan jumlah objek yang banyak, dibutuhkan waktu kurang lebih 4 jam.

\section{B. Saran}

1. Dibutuhkan spesifikasi PC yang lebih memadai dan pengadaan lab Multimedia dalam pengembangan pembuatan animasai kedepan.

\section{DAFTAR PUSTAKA}

[1] Aplikasi Blender, Tersedia di : http://www.blender.org di akses pada tanggal 22 november 2014

\section{[2] DUTY OF CARE}

Rose Raniolo Senior Associate Minter Ellison Lawyers Level 23

525 Collins Street

MELBOURNE VIC 3000

http://www.swtafe.vic.edu.au/staff/policies/doc s/institute/Duty_of_Care_-_Minter_Ellison.pdf [diakses 26 mei 2016]

[3] Ibiz Fernandes. Definisi Animasi "Macromedia Flash Animation \& Cartooning: A creative Guide", McGraw- Hill/Osborn, California, 2002

[4] Reskyanti. Pengertian Adobe Premiere. 2012

[5] Suyanto, M. 2005. Multimedia Alat untuk Meningkatkan Keunggulan Bersaing. Yogyakarta: Penerbit ANDI.

[6] UNDANG-UNDANG

REPUBLIK

INDONESIA NOMOR 11 TAHUN 2008 TENTANG INFORMASI DAN TRANSAKSI ELEKTRONIK DENGAN RAHMAT TUHAN YANG MAHA ESA PRESIDEN REPUBLIK INDONESIA,

http://kemenag.go.id/file/dokumen/UU1108.pdf [diakses 13 november 2015]

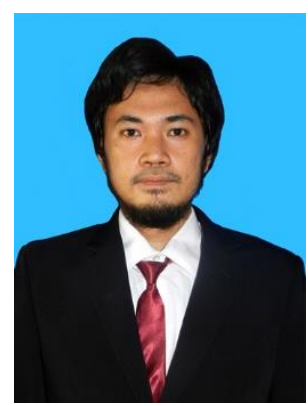

Sekilas dari penulis. Saya bernama lengkap Alan Stevenres Bentelu, anak dari pasangan Stevenson $\mathrm{P}$ Bentelu Amd Pd. dan Dra. Theresia Makarilang. Lahir di Tahuna, pada tanggal 11 November 1992. Saya mulai menempuh pendidikan di SDN 2 Tahuna (1998-2002) dan pindah ke SD KATOLIK SANTO AGUSTINUS TAHUNA (2002-2004). Setelah itu saya melanjutkan pendidikan tingkat pertama di SMP Negeri 1 Tahuna (2004-2007). Selanjutnya saya menempuh pendidikan ke sekolah tingkat atas SMK Negeri 3 Tahuna (2007-2010).

Setelah itu, di tahun 2010 saya melanjutkan pendidikan ke salah satu perguruan tinggi yang berada di Manado yaitu Universitas Sam Ratulangi Manado, dengan mengambil Program Studi S1 Teknik Informatika di Jurusan Elektro Fakultas Teknik. 